\title{
News and Comment
}

\section{Upcoming Meetings and Workshops}

\section{Pacific Branch of the Entomological Society of America Annual Meeting}

The $101^{\text {st }}$ annual meeting of the Pacific Branch of the Entomological Society of America to be held 2-5 April 2017 at DoubleTree by Hilton Portland, Portland, Oregon. Registration is currently open. More information is available at http:// www.entsoc.org/pacific/2017-pacific-branch-annual-meeting.

\section{Northeast Fish \& Wildlife Conference}

The $73^{\text {rd }}$ annual Northeast Fish \& Wildlife Conference, hosted by the Virginia Department of Game and Inland Fisheries, to be held 9-11 April 2017 at the Norfolk Waterside Marriott, Norfolk, Virginia. Registration is currently open. More information is available at http://www.neafwa.org/ann ual-conference.html.

\section{Biodiversity Without Boundaries 2017}

Biodiversity Without Boundaries 2017, hosted by NatureServe Canada, to be held 9-13 April 2017 in Ottawa, Ontario. The theme of the conference is: 'Managing Natural Resources and Biodiversity in a Rapidly Changing World'. Registration is currently open. More information is available at http:// www.natureserve.org/news-events/events/biodiversity-without -boundaries-2017.

\section{Southwestern Branch of the Entomological Society of America Annual Meeting}

The $65^{\text {th }}$ annual meeting of the Southwestern Branch of the Entomological Society of America to be held 9-13 April 2017 at the Wyndham Garden Hotel Austin, Austin, Texas. Registration is currently open. More information is available at http://www.entsoc.org/southwestern/2017-southwest ern-branch-annual-meeting.

\section{US Regional Association of the International Asso- ciation for Landscape Ecology Annual Meeting}

The annual meeting of the US Regional Association of the International Association for Landscape Ecology to be held 9-13 April 2017 at the Hyatt Regency Inner Harbor, Baltimore, Maryland. The theme of the conference is: 'People, Places, Patterns: Linking Landscape Heterogeneity and SocioEnvironmental Systems'. Registration is currently open. More information is available at http://usiale.org/baltimore2017/ \#2017.

\section{The Washington-British Columbia Chapter of the} American Fisheries Society Annual General Meeting

The Washington-British Columbia Chapter of the American Fisheries Society Annual General Meeting to be held 10-13 April 2017 in Spokane, Washington. The theme of the conference is: 'Fisheries Collaborations: Tipping the Scales Toward Success'. Registration is currently open. More information is available at http://agm.wabc-afs.org/.

\section{Northeast Natural History Conference}

The 2017 Northeast Natural History Conference to be held 21-23 April 2017 at the Radisson Hotel, Cromwell, Connecticut. Registration is currently open. More information is available at https://www.eaglehill.us/NENHC_2017/NENHC2017 .shtml.
Canadian Society for Ecology \& Evolution Meeting

The 2017 Canadian Society for Ecology \& Evolution Meeting, hosted by the University of Victoria, to be held 7-11 May 2017 at the Victoria Conference Centre and The Royal BC Museum, Victoria, British Columbia. Registration is currently open. More information is available at http://www.csee2017 .ca/?lang=en.

\section{International Conference on Ecology \& Transportation}

The $9^{\text {th }}$ biennial International Conference on Ecology \& Transportation conference, co-hosted by the Utah and Wyoming Departments of Transportation, with support from the US DOT Federal Highway Administration, to be held 14-18 May 2017 at the Salt Place Convention Center, Salt Lake City, Utah. Registration is currently open. More information is available at http://www.icoet.net/ICOET_2017/index.asp.

\section{Annual Meeting of the Canadian Society of Zoologists}

The $56^{\text {th }}$ annual meeting of the Canadian Society of Zoologists to be held 15-19 May 2017 at the University of Manitoba, Winnipeg, Manitoba. Registration is currently open. More information is available at http://www.csz-scz2017.com/.

\section{Annual Conference on Great Lakes Research}

The International Association for Great Lakes Research's $60^{\text {th }}$ Annual Conference on Great Lakes Research to be held 15-19 May 2017 in Detroit, Michigan. More information is available at http://iaglr.org/conference/about.php.

\section{OE3C 2017 Ontario Ecology, Ethology and}

\section{Evolution Colloquium}

OE3C 2017 Ontario Ecology, Ethology and Evolution Colloquium to be held 18-20 May 2017 at Queen's University, Kingston, Ontario. Registration is currently open. More information is available at http://www.queensu.ca/oe $3 \mathrm{c} 17 /$.

\section{International Urban Wildlife Conference 2017}

The 2017 International Urban Wildlife Conference, hosted by the San Diego State University and the Wildlife Society's Urban Wildlife Working Group, to be held 4-7 June 2017 in San Diego, California. More information is available at http: //www.urban-wildlife.org/index.html.

\section{Society for Freshwater Science Annual Meeting}

The Society for Freshwater Science Annual Meeting to be held 4-8 June 2017 at the Raleigh Convention Center, Raleigh, North Carolina. Registration is currently open. More information is available at http://sfsannualmeeting.org/.

\section{Phycological Society of America Annual Meeting}

The annual meeting of the Phycological Society of America to be held 4-8 June 2017 at the Embassy Suites by Hilton Monterey Bay Seaside, Seaside, California. Registration is currently open. More information is available at http://www.psa algae.org/meetings/2017/6/4/psa-2017-annual-meeting.

\section{Animal Behavior Society Annual Conference}

The $54^{\text {th }}$ annual conference of the Animal Behavior Society to be held 12-16 June 2017 at the University of Toronto's Scarborough Campus, Scarborough, Ontario. More information is available at http://www.animalbehaviorsociety.org/2017 $-\mathrm{sd} /$. 


\section{Francis Cook steps down after long and distinguished service with the Ottawa Field-Naturalists' Club and the Canadian Field-Naturalist}

When Francis Cook stepped down as associate editor in 2016 he completed a staggering 48 years of service ${ }^{1}$ to the Canadian Field-Naturalist (a journal of field biology and ecology with global recognition). He was Editor-in-Chief ${ }^{2}$ for 34 years (Figure 1). Francis' influence on the Ottawa Field-Naturalists' Club, the Canadian Field-Naturalist, and field biology in temperate and arctic North America was not just long in duration, it was immense.

The Canadian Field-Naturalist (1919 onwards) and its predecessors, Transactions of the Ottawa Field-Naturalists' Club (1887-1918) and The Ottawa Naturalist (1879-1887), have had 29 Editors-in-Chief. Only four of these have served for 10 or more years (Brunton 1986): James Fletcher (10 years), Arthur Gibson (12 3/4 years), Douglas Leechman (11 years), and Harold Senn (13 1/4 years). Thus the editorial contribution of Francis Cook is three times that of any other editor over the 136 -year period of publication. The total number of volumes, issues, and pages Francis edited is 35, 137, and 19275 ! This does not include the editorial work done on papers that were submitted to the journal and reviewed but ultimately not published. The amount of editorial work on manuscripts and communication with authors, Associate Editors, printers, Copy Editors, and business managers represented by these figures consumed an enormous amount of time over many years.

The numbers clearly prove that Francis served the Canadian field biology community as an editor for an exceptionally long period, and perhaps longer than anyone else. However, his achievement was not only a function of time, it also had much to do with the way he did the job. The success of peer review in scientific journals ultimately relies on the expertise and good judgement of the editor, who acts as a mediator between reviewers and authors and ultimately decides if and when a paper is ready for publication. Francis consistently made clever editorial decisions and he brought the skills of a great field biologist to the role, which helped to maintain the quality of the science in the journal. He also had a kind and patient disposition that maximized the beneficial outcome of interactions with authors. Because he was so widely respected, he had no difficulty in gathering around him and leading a skilled group of Associate Editors from across North America.

Francis devoted much time to helping authors conceptualize their ideas and write their manuscripts so that acceptance and publication could be achieved and research findings could be effectively communicated. $\mathrm{He}$ was always particularly supportive of independent (noninstitutional) contributors. Under his guidance and encouragement, the Canadian Field-Naturalist published the first of what unfolded as a lifetime of scientific contributions from more than a few independent researchers. When asked if he helped authors perfect their man-

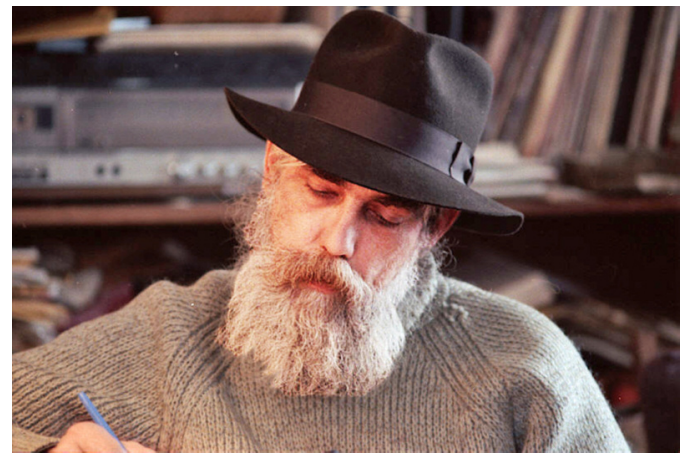

Figure 1. Dr. Francis Cook working on the Canadian FieldNaturalist in 1984. The photo appeared originally in the Canadian Association of Herpetologists Bulletin 18(1). 2010. Photo: Joyce Cook.

uscripts more than may have been necessary to reach publication standard, Francis might have told this story (Cook 2002): Englishman James Smithson, the son of the Duke of Northumberland, mysteriously left his fortune to the United States of America, to found at Washington, under the name of the Smithsonian Institution, an establishment for the increase and diffusion of knowledge among men. The mystery was, why did he leave his money to the United States? James may have admired the equalitarian society of the newly formed United States. It is also speculated that he became embittered by the rejection of one of his manuscripts by the editor of the Royal Society. The Smithsonian Institution, with the greatest collections in the world, was born in Washington in 1846. In other words, if the editor at the Royal Society had helped Smithson to bring his manuscript to publication standard, rather than reject it, the Smithsonian Institution might have ended up in the United Kingdom. This is an amusing way of saying that we cannot help each other enough!

At his core Francis has always been a field naturalist as well as a scientist. As editor, he openly promoted the importance of basic observational input into our understanding of the natural sciences, and he strongly supported publication of important observations in the Canadian Field-Naturalist to make the information available.

Francis was committed to the idea that an independent journal of natural history was needed and could only be supported in Canada by subscriptions by both lay naturalists and employed professionals, as neither group alone would be strong enough to finance a peerreviewed journal. It has proven to be an extremely successful concept over the years. The Canadian FieldNaturalist is regarded both as an essential component of the Ottawa Field-Naturalists' Club and as an effective scientific journal. 
In his first term as editor Francis learned the job from previous editor Robert A. (Bob) Hamilton who would stress again and again, that authors defended each manuscript submitted with the ferocity of a mother with a new child. "Each manuscript involved incredible labour, certainly psychological labour to bring to submission, and was often regarded as perfection in the same way a new child is seen by a parent as flawless. To bring to an author's attention that anonymous strangers have suggested that alterations would be a good idea, is a delicate matter indeed" (Cook 2002). Hamilton's observation reminds us that it is not always easy to be an editor, but Francis dealt effectively with the misunderstandings and differences of opinion among authors, reviewers, editors, and even readers that are routinely encountered in science.

As well as providing a lengthy tenure of excellent editing and leadership for the Canadian Field-Naturalist, Francis made many important contributions and innovations to the publications program of the Ottawa Field-Naturalists' Club. Especially notable was his work on the ad hoc Publications Review Committee, appointed by the Ottawa Field-Naturalists' Club council from 1980 to 1981, with a mandate to improve the definition of the editorial position and to develop a policy guiding the amount of scientific versus popular content published in the journal - an issue about which there were considerable and strong differences of opinion among council members and the editorial team. Francis was respected as both a naturalist and a scientist, and he successfully navigated the delicate relationship that had developed between the Ottawa Field-Naturalists' Club council and Canadian Field-Naturalist supporters. Francis then came to the rescue at a time when the future of the journal seemed uncertain, and stepped forward as editor for a long second term. His understanding of the important role of the Canadian Field-Naturalist as a key, nationally-focused output of the Ottawa Field-Naturalists' Club, as well as its role in the broader science publishing ecosystem in Canada, was exactly what was needed at the time. It continues to serve as a guiding principal for the journal.

From 1984 to 2002 Francis worked with Bob Campbell (Renaud 2011) of the federal Department of Fisheries and Oceans and the Canadian Wildlife Service to publish reports commissioned by the Committee on the Status of Endangered Wildlife in Canada (COSEWIC) on threat status. These included annual reports, status reports, and updates on 89 fishes and 51 marine mammals. In addition, the Canadian Field-Naturalist published status reports on one amphibian, two reptiles, two birds, two mammals, one invertebrate, and 12 plants. Publication in the Canadian Field-Naturalist was very important at the time because COSEWIC had no other way of disseminating the important conservation information presented in the status reports ${ }^{3}$. Additionally, a series of provincial government-supported "status evaluations" that updated status reports on
British Columbia plants was published in 2006 (Canadian Field-Naturalist 120(2)). Papers that made contributions to our understanding of conservation status of species and ecosystems became a regular feature of the Canadian Field-Naturalist thereafter.

During his editorship, Francis strongly promoted "special issues" of the Canadian Field-Naturalist that focused on specific and important topics. The "1980s Peregrine Falcon Update" contained 13 articles reporting current research and updating the analyses presented in the original special issue a decade before (1970, Canadian Field-Naturalist 84(3)), which contributed to a number of successful conservation efforts. Other special issues of lasting value were: "The history of the exploration of the Vascular Flora of Canada, SaintPierre et Miquelon and Greenland" (1995, Canadian Field-Naturalist 109(3)); "A life with birds: Percy A. Taverner, Canadian Ornithologist, 1875-1947” (1996, Canadian Field-Naturalist 110(1)); "The orchids of the Ottawa District" (1997, Canadian Field-Naturalist 111(1)); and "A passion for wildlife: The history of the Canadian Wildlife Service" (1999, Canadian FieldNaturalist 113(1)).

Francis wrote 28 annual reports of editorial work and also made numerous contributions to the Canadian Field-Naturalist as an author in a non-editorial capacity. He published 115 reviews of books, mostly herpetology, and 22 scientific articles about reptiles and amphibians in the journal. He also served as author and co-author of many tributes to Canadian biologists in a number of different fields.

The significant improvements in the Canadian FieldNaturalist made by editors who preceded his second term, Ted Mosquin (vol. 81(1) - vol. 86(3)) and Lorraine Smith (vol. 86(4) - vol. 95(3)), were much appreciated by Francis. He noted that Ted gave the Canadian Field-Naturalist a social conscience and increasing conservation content, and that Lorraine raised editorial standards. Francis continued to promote these values. His recognition of previous editorial achievements also contributed to his success.

Honorary Membership of the Ottawa Field-Naturalists' Club was conferred on Francis "for service to the Club and herpetological work" in 1998 (OFNC 1998), but he remained editor of the Canadian FieldNaturalist for 12 more years and then served as an Associate Editor for five additional years. He received the Ottawa Field-Naturalists' Club Member of the Year Award in 1990 for getting the journal caught up to schedule (OFNC 1990) at a time when production and publication had slowed. In 2010 he received the Ottawa Field-Naturalists' Club Member of the Year Award (Allison et al. 2010), again in recognition of his contributions to the Canadian Field-Naturalist. Part of the citation read: "...he has maintained the Canadian Field-Naturalist as the most scientifically important and visible aspect of the club". For the success of the Canadian Field-Naturalist, the Ottawa Field-Natural- 
ists' Club received the prestigious Richardson Natural History Education Award Trophy in 1996 from Ontario Nature. The award is given for special contributions to natural history education (Pope 1997; Catling et al. 2010: 84).

Francis has served as a very strong member of our Canadian biology team. During his more than 48 years of service to the Ottawa Field-Naturalists' Club, he has extensively advanced two of the three club objectives: "(1) To promote the appreciation, preservation, and conservation of Canada's natural heritage, and (2) To encourage investigation, publish the results of research in all fields of natural history, and diffuse the information as widely as possible". His immense contribution to Canadian and international field biology is a source of great pride.

\section{Literature Cited}

Allison, K., I. Brodo, J. Cipriani, C. Hanrahhan, and E. Zurbrigg. 2010. The Ottawa Field-Naturalists' Club Awards for 2010, Presented April 2011. Francis Cook - Member of the Year. Canadian Field-Naturalist 125: 185. (See also http://www.ofnc.ca/awards/2011/Cook.php).

Brunton, D. F. 1986. Additions to the documentation of the publication history of the Canadian Field-Naturalist and its predecessors. Canadian Field-Naturalist 100: 416-423.
Catling, P. M., B. Bennett, G. Mitrow, F. R. Cook, and J. Cayouette. 2010. One step at a time, a tribute to William J. (Bill) Cody, 1922-2009. Canadian Field-Naturalist 124: 71-96.

Cook, F. R. 1982. Editor's Report for 1981. Canadian FieldNaturalist 96: 220-223.

Cook, F. R. 1986. The "one hundredth" volume of The Canadian Field-Naturalist. Canadian Field-Naturalist 100: 140142.

Cook, F. R. 2002. On being editor of the Canadian FieldNaturalist. A speech delivered to the Ottawa Field-Naturalists' Club annual business meeting in the Victoria Museum, Ottawa, on 8 January 2002.

OFNC (Ottawa Field-Naturalists' Club). 1990. Francis R. Cook, Member of the Year, 1990. http://www.ofnc.ca/aw ards/winners.php\#member-year.

OFNC (Ottawa Field-Naturalist' Club). 1998. Francis R. Cook, Honorary member, 1998. http://www.ofnc.ca/awards /winners.php\#honorary.

Pope, F. 1997. Richards Natural History Education Award. Trail and Landscape 31: 41-42.

Renaud, C. B. 2011. Robert (Bob) Ronald Campbell (19432011): Biologist, Conservationist, Pastor. Canadian FieldNaturalist 125: 370-372.

Paul Catling, Dan Brunton, Jeff Saarela, Frank Pope - OFNC Publications CommitTeE

\footnotetext{
${ }^{1}$ Publications-related work of Francis Cook for the Ottawa Field-Naturalists' Club and dates: Member of the Ottawa FieldNaturalists' Club Publications Committee from 1962 to 1966, and again from 1981 to 2010. Associate Editor for herpetology from 1972 to 1981, and for herpetology and tributes from 2011 to 2016. Editor-in-Chief of the Canadian Field-Naturalist from 1962 to 1966 and again from 1981 to 2010.

${ }^{2}$ There is an honourarium for the Canadian Field-Naturalist editor, but during most of the time Francis served as editor it was transferred to a research support fund at the Canadian Museum of Nature, where he was employed.

${ }^{3}$ Information about endangered species was broadly publicized in the Canadian Field-Naturalist and the journal thus contributed directly to the conservation of wildlife in Canada. COSEWIC status reports were later made available through the Species at Risk Act (SARA) Public Registry http://www.sararegistry.gc.ca/search/advSearchResults_e.cfm?stype=doc\&docID=18.
} 